University of Nebraska - Lincoln

DigitalCommons@University of Nebraska - Lincoln

Faculty Publications from the Harold W. Manter Laboratory of Parasitology

$11-1970$

\title{
Studies on the Helminth Fauna of Alaska. XLIX. The Occurrence of Diphyllobothrium latum (Linnaeus, 1758) (Cestoda: Diphyllobothriidae) in Alaska, with Notes on Other Species
}

\author{
Robert L. Rausch \\ Arctic Health Research Center, rausch@u.washington.edu \\ D. K. Hilliard \\ Arctic Health Research Center
}

Follow this and additional works at: https://digitalcommons.unl.edu/parasitologyfacpubs

Part of the Parasitology Commons

Rausch, Robert L. and Hilliard, D. K., "Studies on the Helminth Fauna of Alaska. XLIX. The Occurrence of Diphyllobothrium latum (Linnaeus, 1758) (Cestoda: Diphyllobothriidae) in Alaska, with Notes on Other Species" (1970). Faculty Publications from the Harold W. Manter Laboratory of Parasitology. 551. https://digitalcommons.unl.edu/parasitologyfacpubs/551

This Article is brought to you for free and open access by the Parasitology, Harold W. Manter Laboratory of at DigitalCommons@University of Nebraska - Lincoln. It has been accepted for inclusion in Faculty Publications from the Harold W. Manter Laboratory of Parasitology by an authorized administrator of DigitalCommons@University of Nebraska - Lincoln. 


\title{
Studies on the helminth fauna of Alaska. XLIX. The occurrence of Diphyllobothrium latum (Linnaeus, 1758) (Cestoda: Diphyllobothriidae) in Alaska, with notes on other species
}

\author{
R. L. Rausch AND D. K. Hilliard \\ Arctic Health Research Center, United States Department of Health, Education, and Welfare, College, Alaska
}

Received June 24, 1970

Rausch, R. L., and D. K. Hilliard. 1970. Studies on the helminth fauna of Alaska. XLIX. The oc-
currence of Diphyllobothrium latum (Linnaeus, 1758) (Cestoda: Diphyllobothriidae) in Alaska, currence of Diphyllobothrium latum (Linnaeus, 1758) (Ces
with notes on other species. Can. J. Zool. 48: 1201-1219.

Cestodes representing six species of the genus Diphyllobothrium Cobbold, 1858, were collected from naturally infected terrestrial mammals in Alaska during the period 1949-1970. Additional specimens were reared in experimentally infected animals. Of the species identified, viz., D. latum (Linnaeus, 1758), $D$. dendriticum (Nitzsch, 1824), D. lanceolatum (Krabbe, 1865), D. ursi Rausch, 1954, D. dalliae Rausch, 1956 , and $D$. alascense Rausch and Williamson, 1958 , all but $D$. alascense were obtained from man after treatment with quinacrine. $D$. latum occurred most commonly in man; $D$. ursi is reported for the first time from this host, and $D$. lanceolatum in man was represented by a single plerocercoid. $D$. lanceolatum, a characteristic parasite of phocids, was found also in dogs; $D$. alascense was obtained only from dogs. In man, rates of infection by Diphyllobothrium spp. were highest in the delta region of the Kuskokwim and Yukon Rivers, western Alaska. Included is a description of D. latum and a discussion of morphologic variation, based upon specimens from Alaska, with a consideration of differential characters of the other species reported. Some biological characteristics of these cestodes are briefly discussed.

Local surveys in northern Canada and in Alaska have shown that cestodes of the genus Diphyllobothrium Cobbold, 1858, are common parasites of aboriginal peoples at high latitudes in North America. Although these cestodes usually have been designated "Diphyllobothrium sp.," in a few cases the name D. latum (Linnaeus, 1758) has been applied. Such determinations have not been well supported by morphological data, so that the occurrence of $D$. latum in northern North America has not been confirmed.

We have assembled and studied in the years 1949 to 1970 a large collection of cestodes of the genus Diphyllobothrium, from experimentally infected animals, from naturally infected animals postmortem, and from man through the use of anthelminthics. We have determined that at least six species of Diphyllobothrium occur in man and (or) other terrestrial mammals in Alaska, and that D. latum is one of three which are found commonly in man in western Alaska. In the present paper we report our findings concerning $D$. latum and discuss some aspects of parasite-host relationships of this and other species of Diphyllobothrium.

\section{Materials and Methods}

Much of our material was obtained in the KuskokwimYukon region from Eskimos, who reside there in scattered settlements. Inhabitants of the villages visited were asked to submit fecal specimens for direct microscopic examination. Those individuals found to be infected by diphyllobothriid cestodes were placed on a fat-free diet for $24 \mathrm{~h}$, after which they were given in the evening $30 \mathrm{~g}$ of magnesium sulfate dissolved in water. The next morning, $100 \mathrm{mg}$ of phenobarbitol were administered, then $1 \mathrm{~g}$ of quinacrine with an equal amount of sodium bicarboriate. Two hours later, $30 \mathrm{~g}$ of magnesium sulfate were again administered. No food was allowed until defecation had occurred. By this method the cestodes were often obtained intact and in satisfactory condition for detailed study. Several specimens from patients were made available by personnel at the hospitals at Bethel and Anchorage

Cestodes obtained alive were relaxed in water and killed by sudden immersion in hot $10 \%$ formalin. The strobilae were stained in Semichon's acetic carmine or Ehrlich's acid hematoxylin, dehydrated in ethanol, cleared in terpineol, rinsed in xylene, and mounted in Permount. Portions of strobilae were stained in a $1 \%$ aqueous solution of methyl green - pyronin to facilitate study of genital ducts and other structures. Superficial tissues, including layers of longitudinal muscle fibers, were removed from portions of strobilae to permit better examination of internal organs. Sagittal and transverse sections were prepared from series of segments from all strobilae studied. For large specimens, best results were obtained when such sections were cut by means of a razor blade with the aid of a stereoscopic microscope, after the specimens had been stained and cleared. All strobilae and sections thereof were mounted on sequentially numbered slides.

The cestodes collected in Alaska were compared with specimens of $D$. latum from the endemic region of northern Europe. The European specimens were provided as follows. (a) By Dr. W. Nyberg, one cestode each from two patients, and part of 14 from one patient, from the vicinity of Pielisjärvi in Finnish Karelia, all expelled at the Central Hospital at Vasa by means of treatment with $e x$ - 
tractum filicis. The patient from whom the 14 were obtained had the typical megaloblastic anemia caused occasionally by $D$. latum. (b) By Dr. V. Freze, one cestode from man and four from dog, all from the Karel'skaia ASSR, USSR. (c) By Dr. F. Kuhlow, portions of strobilae obtained experimentally in man (23-day infection) and in dogs (25-day and 37-day infections).

We usually established experimental infections in laboratory-reared dogs and in laboratory-hatched gulls, Larus glaucescens Naumann. Other animals were used occasionally. Cestodes obtained from experimentally infected animals were fixed and prepared as outlined above.

In this work we have relied especially upon the detailed description of D. latum by Sommer and Landois (1872).

\section{Results}

$D$. latum has been recorded in Alaska almost exclusively from man. To document this determination, we include a description based upon 60 specimens, 17 intact, from man in Alaska, as well as a consideration of observed morphological variation. All measurements given are in millimeters.

\section{DESCRIPTION OF D. latUM FROM ALASKA}

(Figs. 1-4)

Strobila thin, translucent in preserved state, 1560 to 11400 long, with up to about 3600 segments. Strobila attenuated anteriorly, widening posteriad to maximum of 8 to 14 , with superficial longitudinal grooves dorsally and ventrally. Strobilar margins serrate, with margins of individual segments often slightly convex. Anterior segments much wider than long, with length/width ratio increasing posteriad; length/ width ratio of gravid segments $1: 4$ to $1: 1$. Scolex usually clavate (lateral view) when fully relaxed; 1.5 to 1.8 long by 0.6 to 0.8 in maximum width (av. 1.6 by 0.68 ). Bothria deep, extending full length of scolex. Attenuated neck 8.4 to 14.0 long (av. 11.3). Genital Anlagen first visible 18 to 40 (av. 26) posterior to scolex in 34th to 216 th segment (av. 117th). Genital atrium ventral, on midline in anterior one-fifth to one-quarter of segment, about 0.150 deep, and lined by papillae up to 0.030 in diameter and 0.015 to 0.019 high. Genital pore, about 0.200 in diameter, opening on raised, papilla-covered area extending from anterior margin of segment posteriad slightly beyond uterine opening. Uterine pore on midline, 0.260 to 1.240 posterior to genital pore, near posterior edge of distended area, with distance from genital pore increasing in proportion to length of segment. Inner layer of longitudinal muscle fibers 0.097 to 0.146 thick; layer of transverse fibers 0.018 to 0.048 thick. Excretory system including two thin-walled longitudinal ducts, each situated in parenchyma lateral to margin of ovary; anastomosing ducts not observed. Calcareous corpuscles not observed. Testes in single layer, 0.176 to 0.260 by 0.078 to 0.143 , up to about 1200 per segment, in separate, lateral fields, slightly overlapping ovarian lobes dorsally; rarely confluent at anterior and (or) posterior margins of scattered segments. Vasa efferentia forming main branches, usually two from each lateral field, joining vas deferens on midline near level of anterior margin of ovary. Vas deferens, about 0.060 to 0.090 in diameter, taking convoluted course anteriad between dorsal layer of transverse muscle fibers and loops of gravid uterus, to posterodorsal surface of seminal vesicle, entering latter as narrow duct about 0.015 in diameter. Thick-walled $(0.020$ to 0.057 ) seminal vesicle, 0.172 to 0.357 by 0.130 to 0.233 , posterior to proximal end of cirrus sac, with long axis directed posteroventrad, and round to elliptical in lateral view (sagittal section); in dorsal view, often compressed laterally, 0.156 to 0.243 wide, on midline and dorsal to posterior end of cirrus sac. Ovoid, thick-walled (about 0.025 ) cirrus sac, 0.375 to 0.640 by 0.245 to 0.390 in greatest diameter, with long axis directed anterodorsad, opening anteriorly into genital atrium, containing slightly coiled ejaculatory duct, and provided proximally with dark-staining, gland-like cells internally and externally. Cirrus relatively thick, about 0.500 to 0.615 long when fully extruded, and 0.064 to 0.113 in diameter near tip. Vagina, opening posteriorly into genital atrium and extending dorsad as thick-walled tube about 0.060 in diameter, parallel with posterior wall of cirrus sac, turning (near $60^{\circ}$ ) just ventral to seminal vesicle, approaching ventral surface of segment, and narrowing to thin-walled tube as much as 0.052 in diameter running posteriad along midline of segment, there bending dorsad, passing dorsal to ovarian isthmus, and immediately enlarging to form seminal receptacle 0.260 to 0.462 by 0.112 to 0.204 (av. 0.367 by 0.182 ). Seminal receptacle arched, with convex side to right or to left, and alternating irregularly in position from left to right of midline; narrow seminal duct, 0.003 to 0.005 in diameter, extending from fundus of seminal receptacle to 
oviduct. Ovary reticulate, ventral, consisting of two similar lobes near posterior margin of segment and occupying middle one-third of width of segment; posterior portions of ovarian lobes divergent, passing posteriad around Mehlis' gland and often extending slightly into next
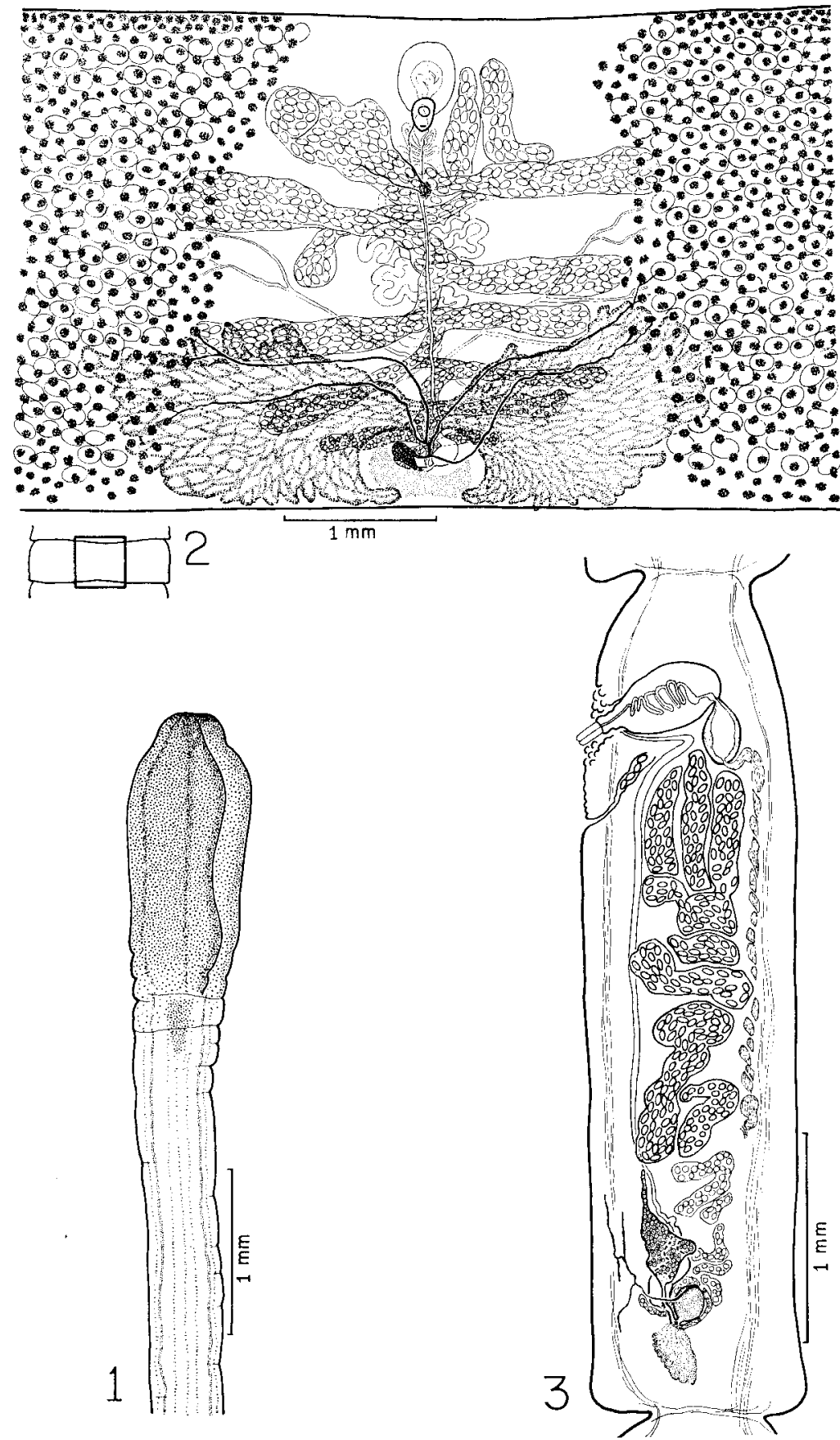

FIGS. 1-3. Morphological characteristics of Diphyllobothrium latum. Fig. 1. Scolex, semilateral view. Fig. 2. Details of genital organs, ventral view. Insert shows area of segment represented. Fig. 3. Relationships of organs as seen in sagittal section (drawn from thick sections of relaxed segments). 
segment. Oöcapt present within funnel-shaped extension of ovarian isthmus. Oviduct arising on midline from latter extension as thick-walled tube, up to 0.040 in diameter, passing ventral to seminal receptacle, receiving seminal duct, and extending to posterior end of vitelline reservoir, joining with duct from latter to form oötype. Ova subspherical, 0.009 to 0.016 in greatest diameter. Vitellaria abundant, arranged in separate lateral fields dorsally and ventrally, slightly overlapping ovarian lobes and loops of gravid uterus. Common vitelline duct arising near ventral surface at posterior end of segment and passing directly dorsad to anterior end of vitelline reservoir. Vitelline reservoir ellipsoid, 0.179 to 0.219 by 0.146 to 0.170 (av. 0.201 by 0.156 ), situated somewhat dorsally in or opposite to concavity formed by arch of seminal receptacle, either to right or left of midline, and connected to oötype by very short duct. Oötype partially surrounded by large Mehlis' gland, latter 0.428 to 0.714 in transverse diameter, about 0.300 in maximum thickness, and extending 0.143 to 0.262 posteriad from oötype. Uterus arising from oötype as thin-walled duct 0.026 to 0.036 in diameter and passing anteriad along dorsal surface of vitelline reservoir; proximally, uterus containing abundant vitelline material, forming numerous coils dorsally, then running anteriad, forming several egg-filled loops. Gravid uterus usually extending anteriad beyond level of posterior margin of cirrus sac, thereafter running posteriad to uterine pore, forming acute angle with ventral surface of segment. Walls of lower uterus about 0.010 thick; metraterm thick-walled, with abundant gland-like cells. Eggs ovoid, 0.062 to 0.076 by 0.042 to 0.051 (av. 0.067 by 0.046 ).

An entire mounted specimen of D. latum, from a 57-year-old male resident of Tanunak (Nelson Island), has been deposited in the Helminthological Collection, U.S. National Museum, No. 70733.

\section{GENERAL CHARACTERISTICS AND MORPHOLOGIC VARIATION}

\section{Scolex}

In relaxed specimens, the scolex was clavate (Fig. 1) and corresponded in shape with that of $D$. latum as shown by Leuckart (1863, fig. 128), Magath (1929, fig. 5), Wardle and McColl (1937, fig. 2), and others.

\section{Strobila}

A well-defined neck was present in all specimens. The strobila was relatively thin, translucent, and white to yellowish in color after fixation (some specimens had been slightly stained by the quinacrine). Along the midline, in a field free of vitelline follicles, the egg-filled uteri appeared as a linear series of disjunct, yellowish to brownish areas, equally visible from both surfaces. Under low magnification, up to five superficial, longitudinal grooves were visible on each side of the central field, dorsally and ventrally.

The largest strobilae were usually those which had developed singly in the host. The strobilae from man in Alaska were indistinguishable from those from man from Finnish Karelia.

\section{Segments}

In all specimens of $D$. latum from Alaska, the earliest segments, derived from the neck, were much wider than long. We found no evidence of "primary strobilization" (sensu Wardle and McLeod, 1952, p. 606) in any. All strobilae corresponded in form to the "Type B" of Kuhlow (1953a, p. 18).

The length/width ratio of the first clearly distinguishable segments was about 0.1 . The segments increased progressively in size, and the anterior portion of the strobila was therefore much attenuated. Maximum width was attained near the end of the first one-third of the strobila in the largest specimens. The rate of increase in the length of the segment exceeded that in width; consequently, the length/width ratio increased posteriad. In a specimen $11400 \mathrm{~mm}$ long made up of 3230 segments, the maximum width of about 7 was attained about 3830 (1748 segments) from the anterior end. At this level, the length/width ratio was about 0.7 . The greater part of the strobila consisted of segments of similar size. Fully developed eggs were present in the terminal portion of the uterus in segments well anterior to the level at which maximum width was attained. In the aforementioned specimen, such eggs were present 540 (987 segments) from the anterior end, where the segments were only 3.3 wide with a length/width ratio of 0.34 .

Fully developed segments (i.e., those of maximum width) varied in shape from strobila to strobila, but were usually more or less rec- 
tangular. Length / width ratios ranged from about 0.3 to 0.5 , although lower ratios were sometimes recorded, and in a few specimens the ratio approached a maximum of 1.0 . However, ratios near 1.0 were at least partly attributable to disproportionate relaxation. The lateral segmental margins were usually slightly convex, but sometimes slightly concave or straight. From one patient, segments were trapezoidal in some of 11 strobilae; these, recovered in large fragments, had an average length of only 3352 . Fully developed segments of maximum width measured as little as 3.5 wide, with a length/ width ratio of about 0.5 . These cestodes were not typical and should be regarded as Kümmerformen.

In transverse section, fully developed segments from different strobilae ranged from about 0.7 to 1.2 in thickness along the midline, in that part occupied by the cirrus sac and terminal portion of the uterus. In all but the most relaxed strobilae, the thickness of the segments decreased laterad. As seen in transverse section, the margins of the segments were rounded.

\section{Musculature}

The musculature of the Alaskan specimens of D. latum did not exhibit any unusual features (cf. Sommer and Landois 1872, pl. VII, fig. 1). No significant differences were observed between specimens from Alaska and those from Finnish Karelia. In transverse section, the thickness of the layer of longitudinal fibers ranged from about 0.030 to 0.076 , depending upon the size of the strobila and degree of relaxation, being thinner over the area surrounding the openings of the genital ducts and uterus in all. The layer of transverse fibers was less variable, usually around 0.020 .

\section{Openings of Genital Ducts}

The common genital atrium and the uterus opened ventrally on the midline, in the anterior half of the segment, where the two pores were situated on the surface of a distention extending about from the anterior margin of the segment posteriad to a level just posterior to the uterine pore. Rounded papillae, some as much as about 0.020 high, usually covered the distended poral area and were present within the genital atrium. The papillae were of comparable size in and around the genital atrium in specimens from
Finnish Karelia. The distended area tended to flatten and disappear in strongly relaxed segments.

When the cirrus was not extruded, the opening of the genital atrium varied in shape from slitlike to round. That of the uterus was usually round and sphincter-like. The margins of both pores contained many dark-staining cells.

The genital pore was well anterior in each segment of all specimens. However, its relative position varied somewhat according to the proportions (length/width) of the segments making up the different strobilae, the extent of variation demonstrated by the ratio obtained when the distance of the pore from the posterior segmental margin was divided by the distance from the anterior margin. The range in this ratio was $1: 2.2$ to $1: 5.3$, with an average of about $1: 4$. The position of the genital pore varied little from segment to segment within a single strobila. The ratios in specimens from man in Finnish Karelia and from dog in the Karelian ASSR fell within the range obtained in specimens from man in Alaska.

The uterine pore is widely separated from the genital pore in $D$. latum, the distance between these pores in segments of maximum width ranging from about 0.360 to 1.240 . The relative distance was nearly constant within a single strobila, whereas the absolute distance varied with the length of the segment; e.g., in a strobila 5559 long, containing 3615 segments, this distance ranged from 0.260 in early gravid segments to 0.520 in those near the posterior end, and in another, 11400 long with 3230 segments, the range was 0.300 to 1.240 . When the distance between the pores was plotted against length of segment, a linear correlation was obtained. In cestodes from man in Finnish Karelia, the distance between the pores in fully developed segments ranged from 0.420 to 0.555 .

\section{Cirrus Sac}

The cirrus sac varied in shape from subspherical to elongate-ovoid or piriform, depending upon its state of contraction. This structure is usually shown as being subspherical or ampulliform in sagittal section (Sommer and Landois 1872, pl. VII, fig. 2; Nybelin 1922, fig. 13; Magath 1929, figs. 16-17).

The size of the cirrus sac varied according to the ultimate size attained by segments in the 
respective strobilae. Although its length in those fully developed ranged from about 0.375 to 0.640 , comparatively little variation in size was noted in single strobilae. The extent of variation in the dimensions of the cirrus sac was determined for a strobila 8079 long, with 3020 segments, by means of sagittal sections of five consecutive segments taken at 50 -segment intervals throughout. At the level of the 900th segment, already gravid, the cirrus sac was 0.375 long, and its full development was attained within the interval of the next 100 segments. From the level of about the 1000th segment posteriad to the end of the strobila, the proportions of the cirrus sac varied irregularly from segment to segment with a range in length of about 0.490 to 0.562 . Diameter varied inversely with length, so that the shortest cirrus sacs tended most toward a spherical shape.

The external seminal vesicle in $D$. latum is situated dorsally, immediately posterior to the cirrus sac. The fully distended organ may be nearly round in sagittal section and in dorsoventral view appeared elliptical or oval. Both size and shape of the seminal vesicle varied with the volume of the contents. The muchcoiled vas deferens occupied the dorsal portion of the central field, extending posteriad approximately to the level of the anterior margin of the ovary, where it enlarged and received the main branches of the vasa efferentia.

\section{Distribution of Testes}

The testes of $D$. latum are arranged in a single layer and are characteristically restricted in distribution to disjunct, lateral fields, usually extending mediad among the loops of the gravid uterus and sometimes overlapping the lateral margins of the ovary (cf. Sommer and Landois 1872 , p. 51 and pl. V). This pattern was typical for cestodes from man in both Alaska and Finnish Karelia. In occasional segments of some strobilae collected in Alaska, the testes were confluent anteriorly, often only in a single row across the midline. Such anterior confluence was observed in the specimen obtained experimentally in man in Germany. The highest proportion of segments with testes confluent anteriorly was observed in cestodes from dog from the Karelian ASSR.

The numbers of testes in Diphyllobothrium spp. are so variable that we believe that they should not be considered as a taxonomic discriminant at the specific level. We did not attempt to determine the range in numbers of testes in the cestodes studied.

\section{Seminal Receptacle and Vagina}

The relationships of the ducts of the female genital complex in $D$. latum have been best portrayed by Sommer and Landois (1872, pl. VIII, fig. 2) and by Nybelin (1922, fig. 14). Nybelin's schematic figure is essentially correct, but that of Sommer and Landois more nearly represents the appearance of the structures as seen in total preparations, with the exception of some relatively minor errors in detail (see below). The relationships of the ducts and associated organs of the female genital complex determined from the study of specimens collected in Alaska are shown in Figs. 3 and 4. Findings were similar in the cestodes from Finnish Karelia.

The seminal receptacle and vagina together make up the duct which runs anteriad to the genital atrium from the female genital complex situated near the posterior margin of the segment. All but the distal (anterior) end of the duct is thin-walled, although in the dilated proximal end, the seminal receptacle, is a layer of muscle fibers not present in the wall of the vagina. As correctly shown by Nybelin (1922, fig. 14), the seminal duct, a short tube of very small diameter, arises from the fundus of the seminal receptacle and empties into the oviduct. Sommer and Landois (1872, pl. VIII, fig. 2) erroneously portrayed the oviduct as emptying into the seminal duct.

In the cestodes from Alaska, the shape and size of the seminal receptacle were relatively uniform in fully developed segments from individual strobilae. Being capable of dilation according to the quantity of its content, the seminal receptacle was not of maximum size in pregravid or early gravid segments. As seen in dorsoventral view at low magnification, it appeared more or less reniform, with the greater curvature usually directed laterad and with the arch formed by the lesser curvature sometimes conforming approximately to the shape of the adjacent vitelline reservoir. However, in sagittal section, it appeared to be essentially piriform, with the fundus ventralmost and the long axis directed almost dorsoventrally. From near the fundus, its diameter decreased dorsad, the 
narrow upper portion becoming somewhat sinuous, turning ventrad and then anteriad, and passing across the dorsal surface of the ovarian isthmus.

From this level, the duct continued anteriad as the vagina, distinguished by its thinner wall. The vagina turned slightly ventrad just anterior to the ovarian isthmus and continued anteriad, gradually more dorsad, passing along the midline between the loops of the gravid uterus. Approaching the uterine pore, it deviated to the right or left past the terminal portion of the uterus, where it turned farther dorsad, reaching the level of the ventral surface of the external seminal vesicle; there, just posterior to the wall of the cirrus sac, it turned abruptly ventrad, making an angle of about $60^{\circ}$, and ran straight to the genital atrium, where it terminated just posterior to the opening of the cirrus sac. Immediately before the last turn, the vaginal walls thickened, with a corresponding decrease in the diameter of the lumen. The wall of the straight, terminal portion contained many dark-staining, presumably glandular, cells.

The vagina was never found to run dorsad beyond the ventral surface of the external seminal vesicle. In some cases, however, the last turn was somewhat U-shaped, evidently because of pressure exerted by the underlying egg-filled uterus.

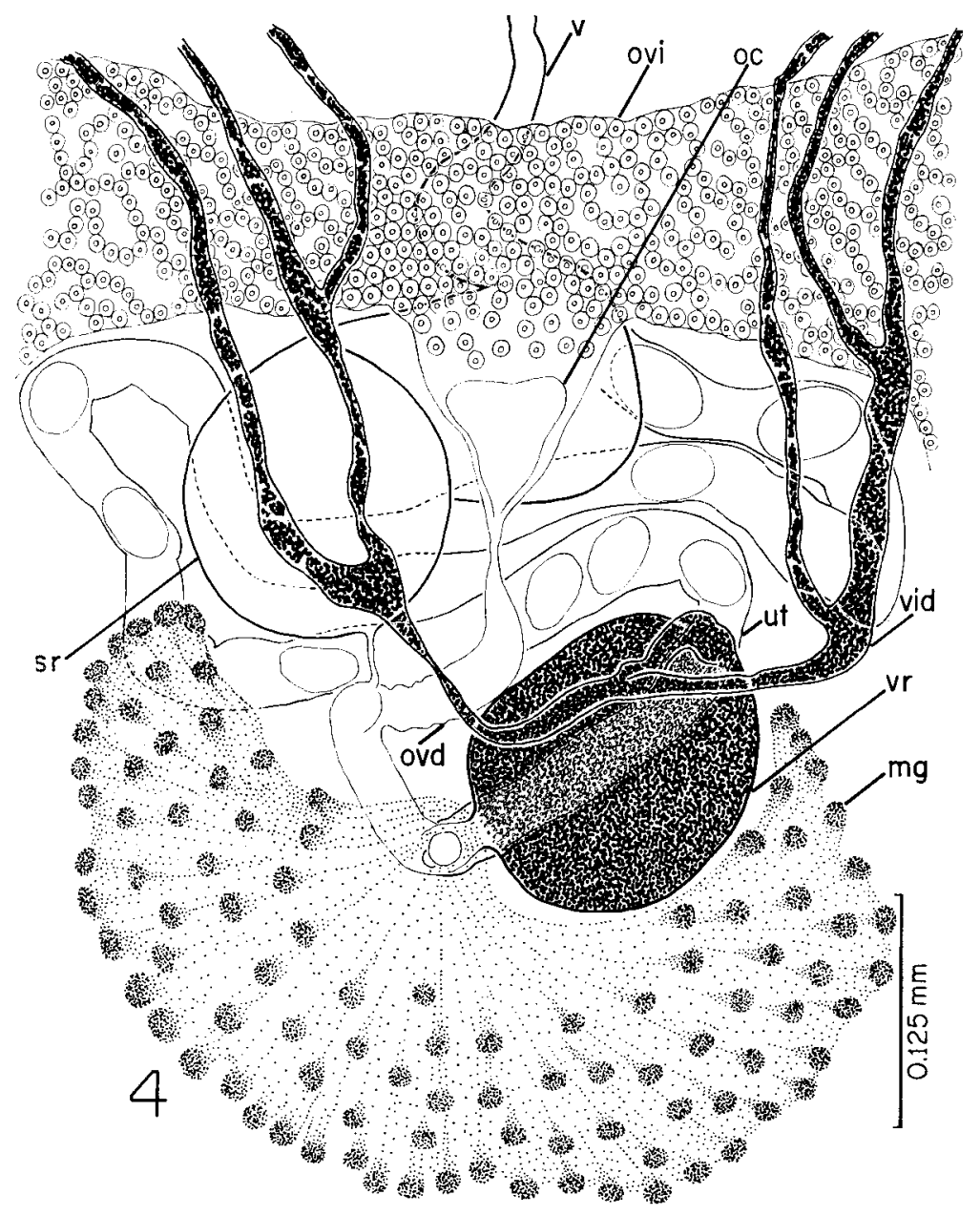

FIG. 4. Details of female genital ducts of Diphyllobothrium latum, ventral view; $s r=$ seminal receptacle, $o v d=$ oviduct, $m g=$ Mehlis' gland, $v r=$ vitelline reservoir, $v i d=$ vitelline duct, $u t=$ beginning uterus, passing dorsal to vitelline reservoir, $o c=$ oöcapt, $o v i=$ ovarian isthmus, $v=$ vagina. 
Distribution of Vitelline Follicles

As shown by Sommer and Landois (1872, pl. IV), the vitelline follicles in $D$. latum are characteristically restricted to disjunct, lateral fields, both ventrally and dorsally. In our material, the follicles frequently overlapped the ends of the loops of the gravid uterus and the lateral margins of the ovary. However, they exhibited even less tendency than did the testes to become confluent across the anterior margin of the segment. They were not confluent in the strobilae from dog in the Karelian ASSR, in which confluence of the testes was not unusual.

Vitelline ducts often extended across the anterior segmental margin and contributed to the vitelline reservoir of the preceding segment. This arrangement of the ducts in D. latum has been shown by Eschricht (1841, Table I, Fig. 5).

\section{Ovary}

The ovary of $D$. latum consists of bilateral, wing-like lobes connected by a narrow isthmus (see Sommer and Landois 1872, pl. IV). The lobes, made up of a loose reticulum of tubules, extend laterad into the respective lateral fields of the segment (Sommer and Landois 1872, p. 57 ; Cohn 1912, p. 26). The anatomical relationships of the ovary were consistent in all material studied. Ovarian shape in the specimens from man in Alaska varied from segment to segment within a single strobila as well as in segments from different strobilae, but the differences observed did not exceed expected limits of intraspecific variation, nor was the range of variation sufficiently great to detract from the value of ovarian conformation as a taxonomic character.

The widest variation in shape involved the posterior portions of the lobes. At midline they are separated by a space in which is situated the rounded (in dorsoventral view) Mehlis' gland. Typically, the medial margins of the lobes remain separated posteriorly. In some segments, the lobes had intact, more or less rounded, posterior margins; in others, single or anastomosing tubules projected irregularly from the posterior margins. The posterior edges of the lobes or extensions from them frequently projected posteriad across the segmental boundary into the following segment. This characteristic was observed in D. latum by Sommer and Landois (1872), who remarked (p. 57) that "Auch überragen ihre unteren Ende mittelst eines platten, streifen- oder bandartigen Anhanges den unteren Grenzrand des Gliedes und greifen in das nächstfolgende über."

In a portion of a strobila reared experimentally by Dr. Kuhlow, the ovarian lobes were confluent across the posterior margin of the segment (see Kuhlow 1953b, fig. 11). Although strands of ovarian tissue often projected mediad from the posterior margins of the lobes in the specimens collected in Alaska, actual confluence was not observed. Kuhlow (1953b, p. 224) noted that confluence of the lobes posteriorly seemed to be characteristic of young strobilae of $\mathrm{Di}$ phyllobothrium spp. His interpretation is supported by our finding that posterior confluence was usual in the four young strobilae, none of which had undergone apolysis, from dog from the Karelian ASSR. Variation in the shape of the ovary in the large strobilae from man in Finnish Karelia was similar to that observed in specimens from man in Alaska.

The ovary of $D$. latum is situated ventrally in the posterior half of the segment. In all material studied, the ovarian isthmus extended across the midline of the segment just anterior to the level of the anterior margin of Mehlis' gland and ventral to the coils of the posterior portion of the uterus. As seen in transverse section, the isthmus was somewhat arched ventrad, with the degree of arching evidently related to the degree of distention of the underlying uterine loops. The relative position of the anterior margin of the ovary varied according to the proportions of the segment; thus, the ovary extended relatively farther anteriad in segments of low length/ width ratio. The organ characteristically occupied the posterior one-quarter to one-third of the middle segmental field, but it extended nearly through the posterior half of segments of very low length/width ratio. The ovarian lobes characteristically extended laterad well beyond the ends of the loops of the posterior portion of the uterus, the anterior margins usually being anteriad to the level of the first transverse uterine loops which contained fully developed eggs. However, the relationships of the loops of the gravid uterus changed as the numbers of eggs greatly increased, so that in some cases fully developed eggs were present in uterine loops lying dorsal to the ovary. Occasionally, pressure exerted on the anterior margins of the ovarian lobes by the distended uterine loops caused 
obvious distortion of the position of the ovary. In one strobila, the loops sometimes extended ventrad so that they perforated and partially disrupted the ovarian tissue. Despite the variations observed in the relative position of the ovary, its characteristic relationships remained discernible.

\section{Uterus}

The first (posterior) portion of the uterus in $D$. latum forms numerous loops or coils dorsal to the ovarian isthmus; this thin-walled part of the uterus and its content assume coloration differentially in methyl green-pyronin and in other stains. From about the level of the anterior margin of the ovary anteriad to the uterine pore, the uterus occupies the full extent of the segment between the dorsal and ventral layers of the transverse muscle fibers; the uterine wall of this portion has a thick external layer of deeply staining cells, but the eggs contained by it were not affected by the stains we used.

The arrangement of the gravid uterus in the material studied was essentially the same as that shown by Sommer and Landois (1872, pl. IV). A series of more or less transverse loops was formed in the middle field of the segment about from the level of the anterior margin of the ovary to the level of the uterine pore anteriorly, then extended anterolaterad in one or two loops past the genital pore; the metraterm ran directly posteromediad to the uterine pore, there forming an acute angle with the ventral surface of the segment. The variation observed in the arrangement of the uterus was evidently related to the proportions of the segment and the numbers of eggs present.

In the strobilae from man in Alaska, segments of maximum width (e.g., in the posterior half of the strobila) were usually near 0.5 in length/ width ratio. In most of them, the transverse uterine loops extended progressively farther laterad from the midline. In segments of low length/ width ratio, the transverse loops were fewer and correspondingly longer, those posterior frequently extending as far laterad as did those in the anterior half of the segment. The loops were most nearly vertical to the median sagittal plane in segments of low length/width ratio, while they were often directed somewhat anteriad in those of higher ratio. The orientation of the loops also varied according to the degree to which the strobila had been relaxed. Bilateral loops were usually present anteriorly, one to each side of the genital pore; less frequently, one loop was present to the right or left.

The presence of large numbers of eggs caused distention of the uterus and distortion of the arrangement of the uterine coils. The eggs were not uniformly distributed, but tended to accumulate distally. As a result, the anterior loops were usually much enlarged, often extending nearly to the anterior margin of the segment and in some cases arching mediad, closely surrounding the genital pore. In one strobila, in which gravid segments were about 12 wide, with a length/width ratio of 0.25 , the entire uterus was distended with eggs and reached or nearly reached both the anterior and posterior segmental margins. In senescent segments, taken from near the posterior end of the strobilae, few if any eggs remained in the anterior uterine loops, in which cases the loops could be readily traced.

Egg

As in other species of Diphyllobothrium, the dimensions and proportions of the egg were variable in $D$. latum. Interstrobilar variation in dimensions was greater than that observed within individual strobilae. Dimensions of the egg of $D$. latum are compared with those of some other species of Diphyllobothrium in Fig. 5.

\section{TAXONOMIC COMPARISONS}

The difficulty in identifying cestodes of the genus Diphyllobothrium has been attributed to inadequate knowledge of the limits of intraspecific morphological variation and of the factors responsible for such extrinsic variation (Stunkard 1949, 1965; Vik 1964). Stunkard (1949, p. 622) expressed the view that "No species of Diphyllobothrium from mammals can be positively and fully characterized at the present time...." However, we believe that morphological characters of reliable diagnostic value can be defined for species of this genus through comparative study of large series of each form in question. From our study of material from a variety of hosts, we conclude that comparatively few species of Diphyllobothrium occur at high latitudes, but that those present can be well characterized, although the nomenclatural uncertainties attributable to the inadequacies of 
the original descriptions of some species make difficult or impossible the tracing of synonymies.

Admittedly, the problem of identification is complicated because the ostensible host-specificity of the strobilar stage of some species seems to be attributable to ecological segregation, rather than to physiological adaptation. The same species not only may be found in different terrestrial hosts, but contrary to earlier concepts, the same species may occur naturally in both terrestrial and marine mammals. Thus, $D$. cordatum (Leuckart, 1863), a common parasite of certain phocids, was found in man and dog (Leuckart 1863, p. 439); D. lanceolatum (Krabbe, 1865), also common in phocids, occurs occasionally in dogs (Rausch et al. 1967) and is reported below for the first time from man; $D$. pacificum (Nybelin, 1931), previously known only from otariids, has been recorded from man (Baer et al. 1967). Another diphyllobothriid cestode, Diplogonoporus balaenopterae (Lönnberg, 1892), a parasite of baleen whales, occurs frequently in man (Morishita 1962) and has been found once in a dog (Rausch 1964).

The infection of terrestrial mammals by these cestodes may be attributable to their eating marine fishes containing the respective plerocercoids. However, accumulating evidence indicates that marine and terrestrial mammals have in anadromous fishes a common source of plerocercoids derived from freshwater ecosystems, and conversely, freshwater fishes may become paratenic hosts of plerocercoids of marine origin when they feed upon anadromous fishes (see below). These interactions seem to account for the diversity of hosts of some diphyllobothriids, and at the same time the recognition of them provides a basis from which the taxonomic status of some of these cestodes may be reconsidered.

Besides D. latum, we have identified five species of Diphyllobothrium from man and (or) other terrestrial mammals in Alaska, viz., D. dendriticum (Nitzsch, 1824), D. lanceolatum, D. ursi Rausch, 1954, D. dalliae Rausch, 1956, and $D$. alascense Rausch and Williamson, 1958. These cestodes are compared morphologically with $D$. latum and some of their biological characteristics are discussed below. In our comparisons we considered the differential characters of $D$. latum to be: thin, weakly muscled strobila, with clavate scolex; genital pore and uterine pore

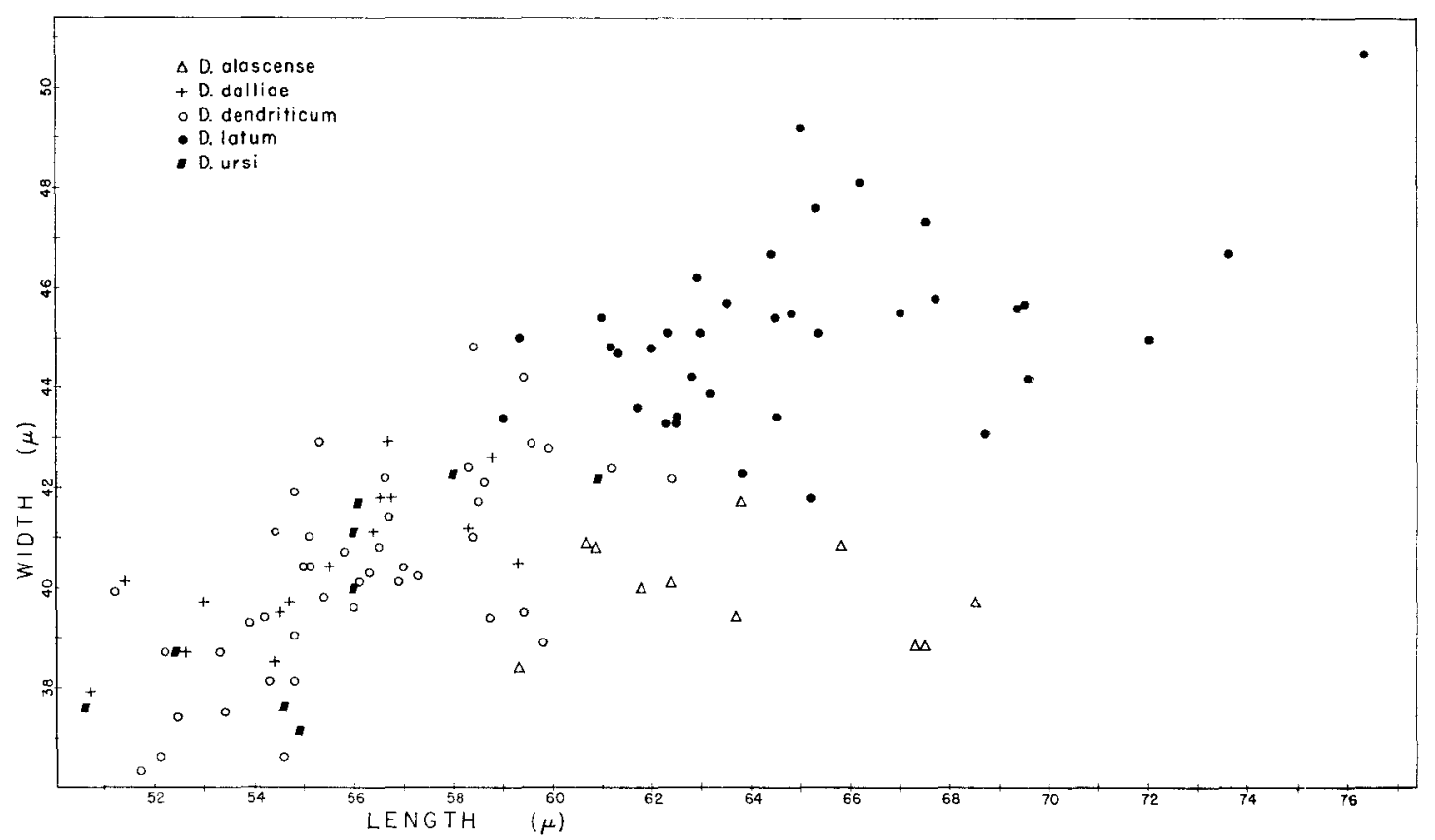

FIG. 5. Comparison of dimensions of eggs of five species of Diphyllobothrium. Each symbol represents average of 50 fully developed eggs measured at random from a single strobila. 
widely separated; distal end of uterus extending posteromediad to uterine pore, forming an acute angle with ventral surface of segment; vagina turning abruptly ventrad just ventral to seminal vesicle, usually forming an angle of near $60^{\circ}$; characteristic shape and relationships of ovary; large size of egg.

\section{D. dendriticum}

Comparative material-We have reared or collected many specimens of $D$. dendriticum. Here, we consider the following examples. Natural infections: strobila from gull, Larus ridibundus Linnaeus, Karelian ASSR; strobilae from man, Chevak (1) and Tanunak (Nelson Island), Alaska (1); experimental infections: 14day-old strobila reared in gull, $L$. ridibundus, by Dr. F. Kuhlow; 18-day-old strobila reared by us in gull, L. glaucescens, from plerocercoid in burbot, Lota lota (Linnaeus); 22-day-old strobila and portion of 65-day-old strobila reared by us in dog and man, respectively, from plerocercoids in trout, Salmo gairdneri Richardson.

In form of strobila, all specimens compared were of "type B" (Kuhlow 1953a, p. 18). The largest (from experimentally infected dog) was 1380 long by as much as 9 wide, with 524 segments. Strobilae of similar size have been obtained from naturally infected gulls and from man in Alaska. In form and anatomy, the cestodes identified as $D$. dendriticum agreed closely with the description by Kuhlow (1953a).

$D$. dendriticum differs macroscopically from D. latum in having a smaller scolex, a strobila less attenuated anteriorly, and gravid segments of distinctly different shape. In our specimens, the segments were anteriorly much wider than long, with the ratio of length/width increasing posteriad. The gravid segments characteristically had concave lateral margins and were therefore widest across the anterior and posterior ends; the more or less pointed projections formed bilaterally at each segmental junction imparted a characteristic appearance to the strobila. The following differences were evident in anatomical details: the testes and vitellaria were typically confluent across the anterior margin of the segment; the position of the genital pore and associated structures varied with the length of the segment, so that the pore could be posterior to ti.e middle in relatively long segments, in the poste- rior portion of strobilae; the seminal vesicle was characteristically dorsal to the relatively small cirrus sac; the uterine pore was on the midline immediately posterior to the genital pore; the distinctively shaped ovarian lobes were directed essentially laterad; the middle loops of the gravid uterus extended farthest laterad; and the egg differed in dimensions (see Fig. 5).

As noted by Markowski (1949) and by Kuhlow (1953a), D. dendriticum occurs naturally in piscivorous birds (primarily in gulls) as well as in terrestrial mammals. The previous record from man is based upon Markowski's (1949) conclusion that D. strictum (Talysin 1932) is a synonym of $D$. dendriticum. The former species was described from Buriat-Mongols on Ol'khon Island in Lake Baikal (Talysin 1932).

$D$. dendriticum appears to have the widest geographic range of any species of Diphyllobothrium in Alaska, and it occurs also in the greatest variety of final hosts. The plerocercoid is common in fishes of the family Salmonidae. We have indirect evidence that such fishes in some areas (e.g., Kenai Peninsula) become infected by feeding upon sticklebacks, Gasterosteus aculeatus Linnaeus, and Pungitius pungitius (Linnaeus). The strobilar stage of $D$. dendriticum was reared by us in 3 of 18 laboratory-hatched gulls which had been fed sticklebacks from a lake in which trout were commonly infected. Detailed observations on $D$. dendriticum will be reported elsewhere.

\section{D. lanceolatum}

Comparative material-This cestode occurs commonly and in large numbers in bearded seals, Erignathus barbatus Erxleben. Representative specimens compared were as follows. Natural infections: strobilae from bearded seal from waters near St. Lawrence Island (3), Hooper Bay (2), Point Barrow (1); from harbor seal, Phoca vitulina Linnaeus, from the mouth of the Kvichak River (3); from dog, Hooper Bay (6), and Kotzebue (1).

Stunkard and Schoenborn (1936) and Markowski (1952) have provided detailed descriptions of $D$. lanceolatum. Although some of our specimens were larger than any reported, they corresponded with the descriptions in all morphological details. The characteristics of the rather conical scolex and lanceolate strobila readily distinguish 
D. lanceolatum from $D$. latum and other species of Diphyllobothrium found in terrestrial mammals.

Contrary to the opinion expressed by Markowski (1952, p. 198), we affirm that D. lanceolatum is not a specific parasite of Erignathus barbatus, although it occurs most commonly in seals of this species. The specimens from dogs were as well developed as and morphologically indistinguishable from those from seals. This cestode may be capable of developing also in man. From a resident of Chevak, treated with quinacrine on 20 February 1959, three well-developed strobilae of $D$. dalliae and 52 plerocercoids and early-stage strobilae were obtained, among which was a single plerocercoid of $D$. lanceolatum (Fig. 6). The unmistakable plerocercoids of this cestode were found by one of us (R. L. R.) in the body cavity of a whitefish, Coregonus sardinella Valenciennes, from a brackish lagoon near Point Barrow in August, 1953 (Fig. 7). Such fishes are the probable source of infection for dogs and potentially for other terrestrial mammals.
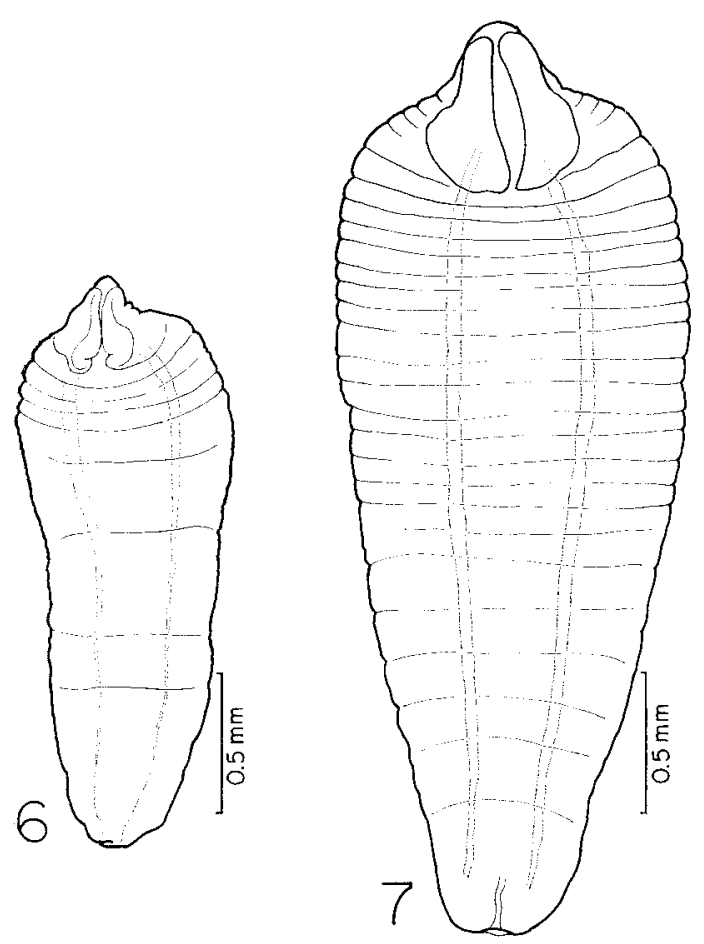

Figs. 6-7. Plerocercoids of Diphyllobothrium lanceolatum from man (Fig. 6), and from whitefish, Coregonus sardinella (Fig. 7).
D. ursi

Comparative material-Natural infections: strobilae from brown bear, Ursus arctos Linnaeus, from Karluk Lake (Kodiak Island) (13); from black bear, Ursus americanus Pallas, from Valdez (1) and Prince of Wales Island (southeastern Alaska) (3); from man, from Karluk Village (Kodiak Island) (1), and Fort Yukon (1).

A common parasite of bears in some regions, D. ursi is reported here for the first time from man. This species, known only from Alaska, is morphologically very similar to $D$. gondo Yamaguti, 1942, which was described from the pilot whale, Globicephala scammoni Cope.

$D$. ursi is a large cestode, attaining a length of as much as $11000 \mathrm{~mm}$ and a maximum width of 23 (Rausch 1954). It differs macroscopically from D. latum in having a larger, more massive scolex, and in the form of the strobila, which is muscular, relatively opaque, and with straight, lateral segmental margins imparting to it a ribbon-like appearance. The genital pore in gravid segments is surrounded by a distended papilliferous area, prominent on living or preserved specimens. In the specimens compared, the following anatomical differences were evident: the gravid uterus and other structures in the central field of the segment were surrounded by an elliptical area free of testes and vitelline follicles; characteristically, the vitelline follicles did not overlap the ends of the uterine loops; the genital pore was at or near the anterior margin of the segment, and the proximal end of the cirrus sac frequently extended anterodorsad into the preceding segment; the cirrus sac, attaining a length of as much as 1.3 , was both relatively and absolutely larger than that of $D$. latum; the vagina was strongly reflexed ventrad just ventral to the seminal vesicle; the terminal portion of the uterus ran more or less directly ventrad to the uterine pore situated closely posterior to the genital pore; the ovarian lobes were well separated and extended laterad so that about half of their width was overlapped by vitelline follicles; the eggs were smaller than those of D. latum (Fig. 5).

All animals found to be infected by $D$. ursi originated in areas where anadromous fishes of the genus Oncorhynchus were present. The plerocercoid of $D$. ursi is known only from red salmon, O. nerka (Walbaum) (Rausch 1954), but it may occur in anadromous fishes of other species. The young red salmon evidently become infected dur- 
ing the period, usually 3 years, spent in fresh water, when they feed upon zooplankton. We found that all of 200 emigrating smolts collected during June, 1956, at the outlet of Karluk Lake, contained one or more plerocercoids of D. ursi. Of 288 spawning adults obtained by us during August-September, 1955, from streams emptying into Karluk Lake, $270(93 \%)$ were infected. Thus, infected red salmon are available to both terrestrial and marine mammals, including toothed whales. Future investigations may show that $D$. ursi is a junior synonym of $D$. gondo Yamaguti, 1942.

\section{D. dalliae}

Comparative material - In western Alaska, this species occurs commonly in man, dog, arctic fox, Alopex lagopus Linnaeus, and gulls. Specimens compared were as follows. Natural infections: strobilae from arctic fox, St. Matthew Island (Bering Sea) (2); from man, Chevak (5); experimental infections: 11-day-old strobilae reared in $\operatorname{dog}(6)$ and in glaucous-winged gull (1), and 21day-old strobila reared in dog, from plerocercoids in blackfish, Dallia pectoralis Bean.

The strobilar stage of $D$. dalliae has been identified only in Alaska, where the plerocercoid is found commonly in blackfish. The plerocercoid has been reported from the same host from the vicinity of Lavrentiia Bay, on the Chukotsk Peninsula of northeastern Siberia (Zhukov 1963).

The strobilae from various hosts were relatively uniform morphologically, ranging to 522 long by as much as 9 wide, and containing up to 294 segments. $D$. dalliae differs macroscopically from $D$. latum in having a much less attenuated

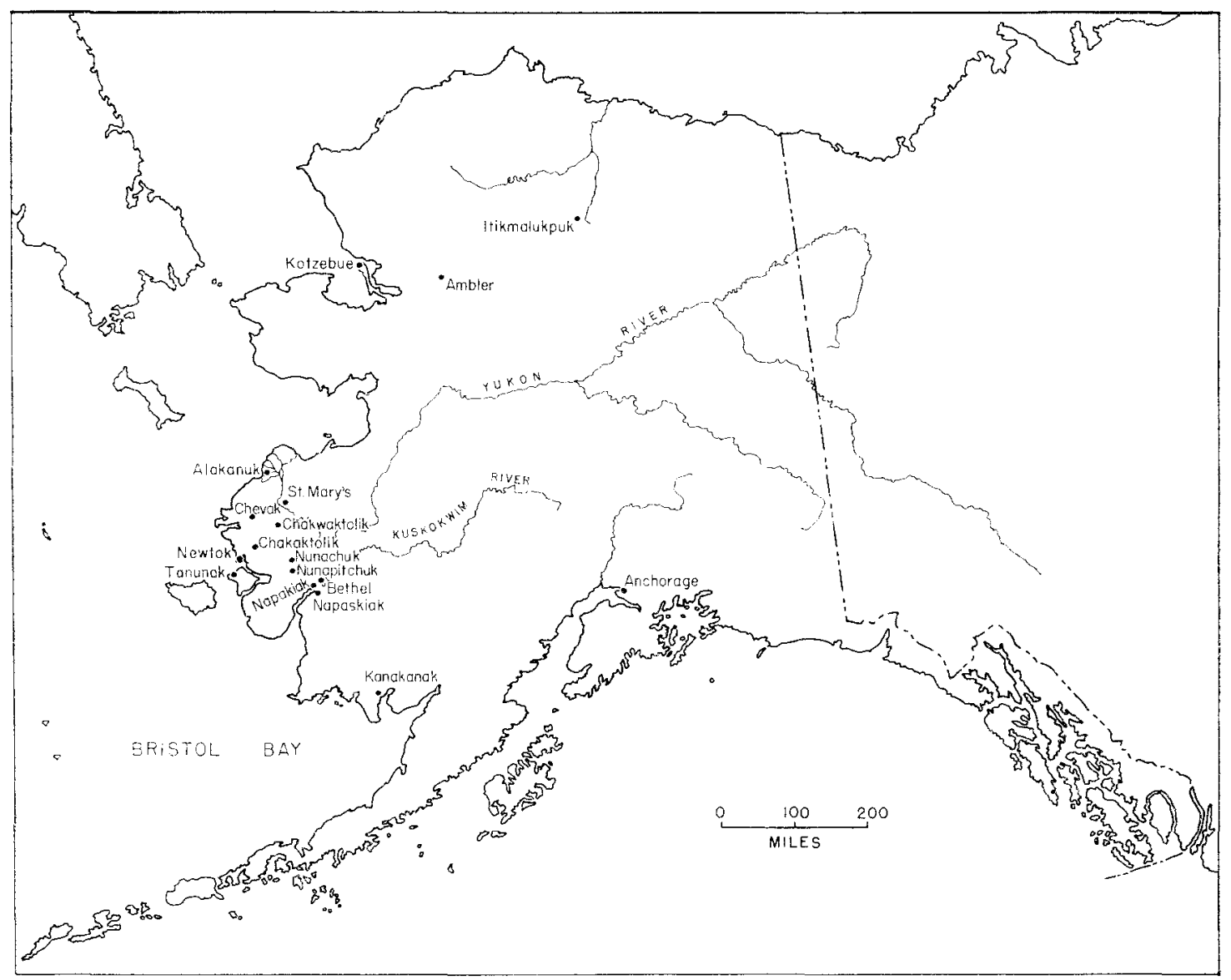

FIG. 8. Map of Alaska showing localities from which specimens of Diphyllobothrium latum have been obtained. 
strobila with relatively few pregravid segments, and a wide, lanceolate scolex. The length/width ratio approached 1.0 in gravid segments, in which the lateral margins were characteristically convex. The strobilar margins were distinctly serrate. The following differences were noted in anatomical details; the testes and vitellaria were confluent across as much as the anterior one-quarter of the segment; the area immediately surrounding the gravid uterus and other structures in the middle field was free of testes and vitelline follicles; the latter overlapped the ends of the loops of the gravid uterus slightly or not at all; the vagina was strongly reflexed ventrad just ventral to the seminal vesicle, which was posterior to the proximal end of the relatively large cirrus sac; the distal portion of the uterus ran directly ventrad to the uterine pore, which lay immediately posterior to the genital pore; the ovarian lobes in shape were rounded to reniform and often were confluent posteriorly; the loops of the gravid uterus frequently extended only to the level of the genital pore and never anterior to the cirrus sac; the eggs were relatively small (Fig. 5).

The plerocercoid of $D$. dalliae occurs in a high proportion of blackfish in western Alaska (Rausch 1956). Such fish are eaten frozen or raw in winter by Eskimos, who capture them in traps in ponds and shallow lakes; consequently, $D$. dalliae is a common parasite of man in the lower Kuskokwim River region. From one resident of Chevak, in addition to 16 well-developed adult cestodes, 124 plerocercoids and earlystage strobilae were recovered after the administration of quinacrine. The strobilae in man were sometimes small and narrow although eggs were usually abundant despite this. $D$. dalliae is probably the most commonly found diphyllobothriid species in dogs, which are often fed blackfish in winter. In a dog from Kwigillingok, autopsied on 21 March 1966 by one of us (D. K. H.), 1087 cestodes identified as $D$. dalliae were present in the small intestine. Most of these were still in a pregravid stage.

Zhukov (1963) reported the plerocercoid of $D$. dalliae from the body cavity of a trout, Salvelinus malma (Walbaum), in northeastern Siberia. The results of our experimental infections using plerocercoids from fishes other than $D$. pectoralis indicate as well that the plerocercoid of $D$. dalliae may not be host- specific but that it may differ morphologically in fishes of other species, perhaps depending upon its site of localization. In the body cavity of blackfish, the infective plerocercoids of $D$. dalliae are distinctive, unlike any that we have collected from other fishes (Rausch 1956). These findings, to be reported separately, may require modification of some of the existing taxonomic concepts.

\section{D. alascense}

Comparative material-D. alascense is a characteristic parasite of dogs in western Alaska. Specimens compared were as follows. Natural infections: strobilae from dog, Hooper Bay (1) and Chevak (3); from harbor seal, Levelock (Kvichak River) (3); experimental infections: 14-day-old strobila from dog and 21-day-old strobilae from $\operatorname{dog}(2)$, reared from plerocercoids in burbot.

We found strobilae of $D$. alascense up to lengths of 730 , with maximum widths of 9 . This cestode differs macroscopically from $D$. latum in having a thick, muscular strobila and a very large, cordate scolex. The following anatomical characters were of diagnostic value: the very large cirrus sac situated at the anterior margin of the segment usually extended into the preceding segment; immediately posterior to the cirrus sac, the vagina turned abruptly dorsad, taking an undulating course past the seminal vesicle to the level of the proximal end of the cirrus sac, then turned and ran ventrad to the genital atrium; the distal portion of the uterus ran directly ventrad, paralleling the vagina, to the uterine pore lying immediately behind the genital pore: the testes in gravid segments were two to three deep.

The rather common occurrence of $D$. alascense in dogs seemed to indicate that the life cycle of this cestode involved freshwater animals (Rausch and Williamson 1958). This opinion was supported by the finding of infected dogs at considerable distances from the coast. However, Hilliard (1960) determined that the egg of $D$. alascense has morphologic characteristics which are typical of eggs of species of Diphyllobothrium occurring in marine mammals, and that the coracidium is adapted to existence in seawater.

In March, 1969, we obtained cestodes of this species in laboratory-reared dogs which had 
been fed plerocercoids from burbots taken in the Kuskokwim River at the village of Tuluksak, about $120 \mathrm{~km}$ (75 mi) upstream from the mouth. The identity of the plerocercoid was confirmed by the infection of two series of dogs, some of which were unweaned, by larvae from burbots collected at the same locality in December, 1969, and January, 1970. The small size ( 1 to $1.5 \mathrm{~mm}$ long) of the plerocercoids and their occurrence in large numbers free in the stomach of the burbots indicated that they had been acquired from other fishes upon which the burbots were feeding. Identifiable remains of such fishes were found in the stomachs of the series, collected in December, of 17 burbots, all of which were large adults, nearly ready to spawn. Their stomachs contained freshwater fishes of two species, blackfish and pike, Esox lucius Linnaeus; in addition, remains of smelt, Osmerus eperlanus dentex Steindachner, an anadromous species, were identified in at least four.

Further evidence of the transfer of diphyllobothriid larvae of marine origin to freshwater fishes was provided by the presence in 25 of the 50 burbots examined of encysted plerocercoids of Pyramicocephalus phocarum (Fabricius, 1780), a host-specific parasite of phocids. We have collected the distinctive larvae (cf. Dollfus 1953, p. 172) of $P$. phocarum from marine fishes in coastal waters: cod, Eleginus gracilis (Tilesius), at Mekoryuk (Nunivak Island) and Tanunak (Nelson Island); sculpins, Myoxocephalus quadricornis (Linnaeus) and Megalocottus platycephalus laticeps (Gilbert), at Mekoryuk, and $M$. quadricornis at Hooper Bay. Also at Hooper Bay we found the plerocercoids free in the stomach of a common porpoise, Phocoena phocoena Linnaeus, and of two seals (Phoca sp.). Free plerocercoids of $P$. phocarum were also found occasionally in the stomachs of burbots. Attempts to rear these cestodes in 16 dogs were unsuccessful, as were two attempts in man.

We believe that burbots become paratenic hosts of the plerocercoids of $D$. alascense through feeding upon infected anadromous or marine fishes, two of which may be the cod, $E$. gracilis, which enters the lower reaches of rivers, and the sculpin, $M$. quadricornis, which reportedly migrates up rivers for considerable distances (Walters 1955). D. alascense is thus another species which may occur in both marine
TABLE I

Diphyllobothrium spp. obtained from some Eskimos after anthelminthic treatment. Only gravid strobilae are listed

\begin{tabular}{|c|c|c|c|}
\hline Sex & Village & D. latum & Other species \\
\hline 오 & Alakanuk & 5 & - \\
\hline$\stackrel{+}{q}$ & Alakanuk & 2 & $\longrightarrow$ \\
\hline$\sigma^{7}$ & Chevak & 1 & - \\
\hline$\sigma^{7}$ & Chevak & - & 6 \\
\hline$q$ & Chevak & 一 & 2 \\
\hline$\underset{P}{+}$ & Chevak & - & 1 \\
\hline$\frac{7}{9}$ & Chevak & $\ldots$ & 1 \\
\hline$\frac{7}{+}$ & Chevak & 一 & 5 \\
\hline$\sigma^{7}$ & Chevak & - & 3 \\
\hline $0^{7}$ & Chevak & - & 16 \\
\hline $0^{\pi}$ & Chevak & - & 2 \\
\hline o & Chevak & - & 1 \\
\hline + & Chevak & - & 1 \\
\hline $0^{\pi}$ & Chevak & $\ldots$ & 1 \\
\hline$\sigma^{\pi}$ & Chevak & - & 2 \\
\hline ơ & Kwigillingok & - & 1 \\
\hline $0^{\pi}$ & Napaskiak & 1 & - \\
\hline $0^{x}$ & Newtok & 1 & - \\
\hline $0^{x}$ & Newtok & 2 & - \\
\hline$\sigma^{7}$ & Newtok & $\overline{1}$ & $\ldots$ \\
\hline$\sigma^{\pi}$ & Newtok & 1 & - \\
\hline q & Newtok & 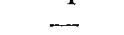 & 2 \\
\hline$\overbrace{+}^{+}$ & Nunapitchuk & 2 & - \\
\hline${ }_{0}^{+}$ & Tanunak & - & 2 \\
\hline$\sigma^{7}$ & Tanunak & - & 1 \\
\hline 0 & Tanunak & 1 & 9 \\
\hline$\sigma^{+}$ & Tanunak & 2 & 10 \\
\hline$\sigma^{7}$ & Tanunak & 1 & - \\
\hline $0^{x}$ & Tanunak & 1 & 一 \\
\hline$\sigma^{x}$ & Tanunak & 1 & - \\
\hline 0 & Tanunak & 1 & - \\
\hline$\sigma^{7}$ & Tanunak & 1 & - \\
\hline \% & Tanunak & 1 & - \\
\hline${ }_{+}^{+}$ & Tanunak & 1 & - \\
\hline
\end{tabular}

and terrestrial mammals. Eggs found in the feces of an Eskimo resident of Newtok were tentatively identified as those of this species, but the cestode was not obtained.

Further observations on the development of D. alascense will be reported elsewhere. The taxonomic status of this species also will be considered separately.

\section{Discussion}

The occurrence of cestodes of genus Diphyllobothrium in aboriginal peoples at high latitudes in North America has been noted by several investigators. Such cestodes have been reported in northern Canada, by Brown et al. (1948), Wolfgang (1954), Arh (1960), Laird and Meerovitch (1961), and Cameron and Choquette (1963); and in Alaska, by Hitchcock (1950, 1951), Fournelle et al. (1958), and Rausch et al. (1967). 
Although some of these cestodes were considered probably to be $D$. latum, their identities have remained uncertain (see Cameron 1945, p. 21). On the basis of eggs found in feces of Eskimos in Alaska, Hitchcock (1951, p. 310) referred to $D$. latum as being ". . . the only cestode found ...," but she applied the designation "Diphyllobothrium sp." elsewhere in the same paper. Ward (1930, p. 22) stated that he had a cestode from a black bear killed on the Naha River in southeastern Alaska, which was “. . . very similar to the broad tapeworm of man ..." Skinker (1931) reported D. latum from a bear killed at Ketchikan. One of the cestodes from this animal (USNM Helm. Coll. No. 28551), kindly lent to us by Dr. W. W. Becklund, was identified by us as $D$. ursi. Both localities are on Revillagigedo Island.

$D$. latum appears to be the most common species of Diphyllobothrium in man in Alaska (Table I). Although its known distribution is extensive (Fig. 8), it has been recorded most frequently in western Alaska, where fishes make up a large part of the Eskimos' diet. The highest rates of infection have been observed in the villages in the region between the deltas of the Kuskokwim and Yukon Rivers. We have obtained this cestode on two occasions from Caucasians from the vicinity of Anchorage.

The intermediate hosts of $D$. latum have not been identified in Alaska. At least two species of copepods known to serve as the first intermediate host in Eurasia occur in the region: Diaptomus gracilis Sars is widely distributed in the drainage of the Kuskokwim River (M. S. Wilson, personal communication), and Cyclops scutifer Sars is a common limnetic species (Yeatman 1959, p. 800). In Alaska, other copepods might be involved in the life cycle, since the procercoid does not appear to be highly host-specific (Dubinina 1957).

The relatively high rates of infection in man in some areas, as determined by the presence of eggs in feces, suggest that the plerocercoid of $D$. latum occurs in fishes which are regularly used as food, consumed uncooked, among which are blackfish, stickleback, and pond smelt, Hypomesus olidus (Pallas). However, the plerocercoids we have found in these fishes differed morphologically from that of $D$. latum (based upon comparisons of specimens from burbot, $L$. lota, from the Elbe River, Germany, and from
Pielisjärvi, northern Finnish Karelia, provided respectively by Dr. F. Kuhlow and Dr. W. Nyberg), and the cestodes we reared from such plerocercoids in experimentally infected animals represented other species of Diphyllobothrium. Although we have not dissected large numbers of fishes, we have found in Alaska that those fish of species commonly involved in the life cycle of $D$. latum in Eurasia either have not been infected, as in the case of pike, or contain plerocercoids of other diphyllobothriid species, as in burbot. Data on the occurrence of plerocercoids in some fishes from the endemic region are summarized in Table II. With the exception of the 50 burbots obtained at Tuluksak, all of these fishes were collected in the Kuskokwim River and nearby waters, from the village of Napaskiak south to the mouth of the river and north along the coast as far as Scammon Bay. Most were obtained in the vicinity of the villages of Napaskiak, Hooper Bay, and Chevak.

Since 1950, we have reared in dogs and glaucous-winged gulls several hundred specimens of Diphyllobothrium, most frequently $D$. dendriticum and D. dalliae, from plerocercoids obtained from fishes in various parts of Alaska. The species of fishes from which cestodes have been reared experimentally are listed in Table III.

TABLE II

The occurrence of plerocercoids of Diphyilobothrium spp. in fishes in the region of the lower Kuskokwim River

\begin{tabular}{|c|c|c|c|}
\hline Species & $\begin{array}{l}\text { Number } \\
\text { examined }\end{array}$ & $\begin{array}{l}\text { Number } \\
\text { infected }\end{array}$ & $\begin{array}{l}\text { Percent } \\
\text { infected }\end{array}$ \\
\hline $\begin{array}{l}\text { Oncorhynchus tscha- } \\
\text { wytscha (Walbaum) }\end{array}$ & 19 & - & $\ldots$ \\
\hline o. kisutch (Walbaum) & 10 & - & - \\
\hline $\begin{array}{l}\text { Stenodus leucichthys } \\
\text { (Pallas) }\end{array}$ & 16 & - & - \\
\hline $\begin{array}{l}\text { Coregonus sardinella } \\
\text { Valenciennes }\end{array}$ & 33 & 24 & 73 \\
\hline C. laurettae Bean & 102 & - & - \\
\hline C. nasus (Pallas) & 52 & - & - \\
\hline C. pidschian (Gmelin) & 35 & - & $\bar{\sigma}$ \\
\hline $\begin{array}{l}\text { Osmerus eperlanus } \\
\text { dentex Steindachner }\end{array}$ & 480 & 263 & 55 \\
\hline $\begin{array}{l}\text { Hypomesus olidus } \\
\text { (Pallas) }\end{array}$ & * & * & $* a$ \\
\hline Esox lucius Linnaeus & 73 & - & $\longrightarrow$ \\
\hline Dallia pectoralis Bean & 301 & 185 & 61 \\
\hline Lota lota Linnaeus & 50 & 50 & $100^{b}$ \\
\hline $\begin{array}{l}\text { Pungitius pungitius } \\
\text { (Linnaeus) }\end{array}$ & 421 & 71 & 17 \\
\hline Total: & 1592 & 593 & \\
\hline
\end{tabular}


The only important final host of $D$. latum in western Alaska appears to be man. Not only do dietary habits favor the infection of man by fish-borne parasites, but the common practice of discarding human excreta into ponds and rivers enables the eggs of diphyllobothriid cestodes to find suitable conditions for development. Under such conditions, no other final host would be essential to perpetuate $D$. latum in this region.

Although many dogs are kept in some of the villages, wild mammals which might serve as the final host of $D$. latum are comparatively few in the endemic region. There, the common wild carnivores are mustelids, viz., otter, Lutra canadensis (Schreber), mink, Mustela vison Schreber, and ermine, $M$. erminea Linnaeus, of which we have examined small numbers. We have found none infected by Diphyllobothrium spp. there or elsewhere in Alaska. Petrov and Dubnitskii (1959) observed that mustelids kept on fur farms did not become infected by $D$. latum when maintained on raw fish, although foxes did so; they also were unsuccessful in their attempts to infect 21 mink experimentally. Both arctic foxes and red foxes, Vulpes vulpes Linnaeus, occur in the endemic region. Cestodes of the genus Diphyllobothrium are relatively common parasites of these foxes, but $D$. latum is rare in them. Our only records of this cestode from animals other than man in Alaska are: red fox, Ambler (northwestern Alaska); arctic fox, Itikmalukpuk Creek (central Brooks Range); dog, Kotzebue.

Because dogs are regularly fed fishes in western Alaska, a high rate of infection by

TABLE III

Origin of plerocercoids from which Diphyllobothritum spp. were rcared in experimental animals

\begin{tabular}{lcc}
\multicolumn{1}{c}{ Species } & Dog & Gull \\
\hline Salmo gairdneri Richardson & + & + \\
Salvelinus malma (Walbaum) & + & + \\
S. namaycush (Walbaum) & + & - \\
Oncorhynchus nerka (Walbaum) & + & + \\
Coregonus sardinella Valenciennes & + & + \\
Thymallus arcticus signifer & + & + \\
$\quad$ (Richardson) & + & + \\
Ssmerus eperlanus dentex & + & - \\
Steindachner & + & + \\
Dallia pesus olidus (Pallas) & + \\
Lota lota Linnaeus Rean & + & + \\
Cottus cognatus Richardson & + & - \\
Plingitius pungitius (Linnaeus) & + & - \\
\hline
\end{tabular}

diphyllobothriid cestodes might be expected in these animals. Of 97 dogs autopsied by us in this region, 57 harbored cestodes of the genus Diphyllobothrium. Heavy infections, with hundreds of cestodes, were not unusual in this sample. D. latum was not identified in any, although some of the small, immature strobilae could not be classified specifically.

The first recognized autochthonous case of $D$. latum in man in North America was that reported by Nickerson (1906), in a child born in Minnesota. Subsequent investigations of others led to the conclusion that $D$. latum became established in eastern North America after its introduction by immigrants from the endemic regions of Europe (Magath 1929; Ward 1930). It appears that D. latum is indigenous in Alaska and perhaps in northern Canada. However, the possibility exists that it was introduced in Alaska by Europeans during the late 18th century. The identification of $D$. latum among Eskimos of remote areas of arctic Canada would indicate that it is indigenous in northern North America.

\section{Acknowledgments}

We received comparative material from Dr. F. Kuhlow, Institut für Schiffs- und Tropenkrankheiten, Hamburg; Dr. W. Nyberg, Central Hospital of Vasa (Finland); Dr. V. Freze, Helminthological Laboratory, Academy of Sciences of the USSR, Moscow; and Dr. W. W. Becklund, Animal Disease and Parasite Research Division, U.S. Department of Agriculture, Beltsville. Mr. K. A. Neiland and Mr. J. J. Burns, Alaska Department of Fish and Game, Fairbanks, provided cestodes collected by them in Alaska. Mrs. Mildred S. Wilson, Anchorage, informed us concerning the identity and distribution of certain copepods in Alaska. A number of cestodes was provided by medical personnel of the U.S. Public Health Service area hospitals in Alaska. Dr. N. J. Wilimovsky, University of British Columbia, Vancouver, identified certain fishes. Laboratory space and logistic support at Point Barrow were provided on several occasions by the Naval Arctic Research Laboratory, Office of Naval Research. Dr. F. S. L. Williamson, now at the Chesapeake Bay Center for Field Biology, Edgewater, Maryland, contributed much by his participation in field and laboratory investigations during the 
period 1955-1964. We were often aided in Alaska by personnel of the Bureau of Indian Affairs and wish especially to acknowledge the assistance of Mrs. Mary McDougall Gillespie and Mr. John Gordon. At the Arctic Health Research Center, Dr. F. H. Fay made numerous collections and assisted with experimental infections; Mrs. V. R. Rausch prepared the figures; Mr. G. C. Kelley prepared photographs. To these persons we express our sincere thanks.

ArH, I. 1960. Fish tapeworm in Eskimos in the Port Harrison area, Canada. Can. J. Public Health, 51: $268-271$.

Baer, J. G., H. Miranda C., W. Fernandez R., and J. MEDINA T. 1967. Human diphyllobothriasis in Peru. Z. Parasitenk. 28: 277-289.

Brown, M., R. G. Sinclair, L. B. Cronk, G. C. Clark, and E. KUITUNEN-EKBAUM. 1948. Intestinal parasites of Eskimos on Southampton Island, Northwest Territories. A preliminary survey. Can. J. Public Health, 39: $451-454$.

CAMERON, T. W. M. 1945. Fish-carried parasites in Canada. Can. J. Comp. Med. 9: 245-254, 283-286, 302-311.

Cameron, T. W. M., and L. P. E. Choquette. 1963. Parasitological problems in high northern latitudes, with particular reference to Canada. Polar Record, 11: $567-$ 577.

CoHN, E. 1912. Ủber Diphyllobothrium stemmacephalum Cobbold. Inaug.-Diss., Zool. Mus., Univ. Königsberg.

Dollfus, R. PH. 1953. Aperçu général sur l'histoire naturelle des parasites animaux de la morue Atlanto-Arctique Gadus callarias L. (= morhua L.). Encyc. Biol. XLIII. Lechevalier, Paris.

Dubinins, M. N. 1957. K voprosu o spetsifichnosti u predstavitelei sem. Diphyllobothriidae Lühe, 1910. Tr. Leningrad. Obshchest. Estestvoispt. 73: 181-187.

EsCHRICHT, D. F. 1841. Anatomisch-physiologische Untersuchungen über die Bothryocephalen. Nova Acta Acad. Nat. Curios. 19, Suppl. 2. Breslau.

Fournelle, H. J., I. L. Wallace, and V. Rader. 1958. $A$ bacteriological and parasitological survey of enteric infections in an Alaskan Eskimo area. Amer. J. Public Health, 48: 1489-1497.

Hilliard, D. K. 1960 . Studies on the helminth fauna of Alaska. XXXVIII. The taxonomic significance of eggs and coracidia of some diphyllobothriid cestodes. J. Parasitol. 46: 703-716.

HitchCOCK, D. J. 1950. Parasitological study on the Eskimos in the Bethel area of Alaska. J. Parasitol. 36 . 232-234.

- 1951. Parasitological study on the Eskimos in the Kotzebue area of Alaska. J. Parasitol. 37: 309-311.

Kunlow, F. 1953a. Über die Entwicklung und Anatomie von Diphyllobothrium dendriticum Nitzsch 1824. Z Parasitenk. 16: 1-35.

1953b. Beiträge zur Entwicklung und Systematik heimischer Diphyllobothrium-Arten. Z. Tropenmed. Parasitol. 4: 203-234.

Laird, M., and E. Meerovitch. 1961. Parasites from northern Canada. I. Entozoa of Fort Chimo Eskimos. Can. J. Zool. 39: 63-67.

LeUCKart, R. 1863. Die menschlichen Parasiten und die von ihnen herrührenden Krankheiten. Vol. 1. Winter'sche Verlagshandlung, Leipzig und Heidelberg.
MaGath, T. B. 1929. Experimental studies on Diphyllobothrium latum. Amer. J. Trop. Med. 9: 17-48.

MARKOWSKI, S. 1949. On the species of Diphyllobothrium occurring in birds, and their relation to man and other hosts. J. Helminthol. 23: 107-126.

- 1952. The cestodes of pinnipeds in the Arctic and other regions. J. Helminthol. 26: 171-214.

MorishitA, K. 1962. [Studies on Diplogonoporus.] (In Japanese.) Progr. Parasitol. Japan, 2: 1-24.

Nickerson, W. S. 1906. The broad tapeworm in Minnesota, with the report of a case of infection acquired in the state. J. Amer. Med. Ass. 46: 711-713.

NyBELIN, O. 1922. Anatomisch-systematische Studien über Pseudophyllideen. Inaug.-Diss., Univ. Upsala, Göteborg.

Petrov, A. M., and A. A. DubnitskiI. 1959. K voprosu o vospriimchivosti pushnykh zverei semeistva kun'ikh (Mustelidae) k zarazheniju Diphyllobothrium latum. Biul. Nauch.-Tekh. Inf. Vseso. Inst. Gel'mint. Im. K. I, Skriabina, 5: 73-74.

RAUSCH, R. L. 1954. Studies on the helminth fauna of Alaska. XXI. Taxonony, morphological variation, and ecology of Diphyllobothrium ursi $\mathrm{n}$. sp. provis. on Kodiak Island. J. Parasitol. 40: 540-563.

- 1956. Studies on the helminth fauna of Alaska. XXVIII. The description and occurrence of Diphyllobothrium dalliae n. sp. (Cestoda). Trans. Amer. Microsc. Soc. $75: 180-187$.

- 1964. Studies on the helminth fauna of Alaska. XLI. Observations on cestodes of the genus Diplogonoporus Lönnberg, 1892 (Diphyllobothriidae). Can. J. Zool. 42: 1049-1069.

RAUSCH, R. L., E. M. SCOTT, and V. R. RAUSCH. 1967. Helminths in Eskimos in western Alaska, with particular reference to Diphyllobothrium infection and anaemia. Trans. Roy. Soc. Trop. Med. Hyg. 61: 351-357.

RausCH, R. L., and F. S. L. Williamson. 1958. Studies on the helminth fauna of Alaska. XXXIII. The description and occurrence of Diphyllobothrium alascense $\mathrm{n}$. sp. (Cestoda). Z. Tropenmed. Parasitol. 9: 64-72.

SkINKeR, M. S. 1931. Diphyllobothrium latum from bears in North America. J. Parasitol. 18: 55.

Sommer, F., and L. LANDOIS. 1872. Ueber den Bau der geschlechtsreifen Glieder von Bothriocephalus latus Bremser. (Beitrag zur Anatomie der Cestoden.) $\mathrm{Z}$. Wiss. Zool. 22: 40-99.

STUNKARD, H. W. 1949. Diphyllobothrium stemmacephalum Cobbold, 1858 and D. latum (Linn., 1758). J. Parasitol. 35: 613-624.

1965. Variation and criteria for generic and specific determination of diphyllobothriid cestodes. J. Helminthol. 39: 281-296.

Stunkard, H. W., and H. W. Schofnborn. 1936. Notes on the structure, distribution, and synonymy of $\mathrm{Di}$ phyllobothrium lanceolatum. Amer. Mus. Novitates, 880: $1-9$.

TALYSIN, TH. 1932. Dibothriocephalus strictus n.sp. Menschenparasit des Baikalgestades. Z. Parasitenk. 4: $722-729$.

VIK, R. 1964. The genus Diphyllobothrium. An example of the interdependence of systematics and experimental biology. Exp. Parasitol. 15: 361-380.

WALTERS, V. 1955. Fishes of western arctic America and eastern arctic Siberia. Taxonomy and zoogeography. Bull. Amer. Mus. Natur. Hist. 106: 259-368.

WARD, H. B. 1930. The introduction and spread of the fish tapeworm (Diphyllobothrium latum) in the United States. DeLamar Lectures, 1929-1930. Williams and Wilkins, Baltimore. 
WARDLE, R. A., and E. L. MCColl. 1937. The taxonomy of Diphyllobothrium latum (Linné, 1758) in western Canada. Can. J. Res. D, 15: 163-175.

WARDLE, R. A., and J. A. MCLeOD. 1952. The zoology of tapeworms. Univ. Minnesota Press, Minneapolis.

WOLFGANG, R. W. 1954. Indian and Eskimo diphyllobothriasis. Can. Med. Ass. J. 70:536-539.
YeatMAN, H. C. 1959. Cyclopoida. In Fresh-water biology. Edited by W. T. Edmondson. John Wiley and Sons, New York. pp. 795-815.

ZHUKov, E. V. 1963. Parazitofauna ryb Chukotki. Soobshchenie II. Endoparaziticheskie chervi morskikh i presnovodnykh ryb. Parazitol. Sb. 21: 96-139. 